\title{
27- Garip Poetikası ekseninde Orhan Veli şiirinde şairanelik ve eda sorunu
}

\section{Bekir Şakir KONYALI ${ }^{1}$}

APA: Konyalı, B. Ş. (2021). Garip Poetikası ekseninde Orhan Veli şiirinde şairanelik ve eda sorunu. RumeliDE Dil ve Edebiyat Araştirmaları Dergisi, (25), 429-438. DOI: 10.2900o/rumelide.1032434.

$\ddot{\mathbf{O} z}$

Garip önsözü, Orhan Veli ve arkadaşlarının (Oktay Rıfat Horozcu ve Melih Cevdet Anday) şiirlerini savunmak, şiir anlayışlarını ortaya koymak için kaleme aldıkları bir poetika metnidir. Metni kaleme alan hareketin öncü ismi Orhan Veli'dir. Metinde dönemin mevcut şiirine itiraz ve eleştiriler sıralanarak gerekçelendirilir. Şairane eda, bu itiraz ve eleştirilere kaynaklık eden bir kavram olarak mevcut şiiri betimlemek için kullanılır. Orhan Veli’ye göre mevcut şiirdeki şairane eda, verili kelime hazinesinin dışına çıkamamanın bir sonucudur. Ancak bu kelimelerin Orhan Veli'nin itirazına konu olan mevcut şiirin diğer bileşenleriyle (vezin, kafiye, söz sanatları, sanatta tedahül vb.) hareket kazandığı düşünüldüğünde şairane eda, bir bütün olarak karşı çıkılan mevcut şiirin temel bir vasfına dönüşmektedir. Buradan bakıldığında şairane edanın reddi, dili şiire bir ağırlık olarak davet eden; buna bağlı olarak da dilde yüceyi, aşkını, ideali işaret eden kelimelerin ve bu kelimelerin hareket kazandığı formların reddi olmaktadır. Şairane edanın karşı kutbunda yer alan ve Garip şiirine asıl hüviyetini kazandıran şairane olmayan eda ise Garip şiirinin poetikasında tam olarak açılığa kavuşturulmaz. Bu yazının amaçlarından biri, bu açıklı̆̆a kavuşturma işlemini Garip şiirinin bizatihi kendisine ve bu şiire getirilen eleştiri ve yorumlara başvurarak gerçekleştirmektir. Bir diğer amaç ise şairane olmayan edanın çözümlenmesiyle Garip şiirinin temel zihniyet ve duyarlılı̆̆ına işaret eden arka planını görünür kılmak, bu şiir anlayışının imkân ve problemlerini göstermektir.

Anahtar kelimeler: Modern Türk şiiri, Orhan Veli, poetika, eda, şairane eda

\section{Orhan Veli's poetry: The problem of poetesque and poetic tone in Garip Movement}

\begin{abstract}
The Garip preface is a poetic text written by Orhan Veli and his friends (Oktay Rufat Horozcu and Melih Cevdet Anday) to defend their poetics. The leading name of the movement that wrote the text is Orhan Veli. In the text, objections and criticisms to the current poetry of the period are listed and justified. The poetesque tone is used to describe the current poetry in their time as a concept that is the source of these objections and criticisms. According to Orhan Veli, the poetesque tone in the current poem is the result of not being able to go beyond the vocabulary given in the poem. However, when it is considered that these words act with the other components of the existing poem (meter, rhyme, similitude, metaphore, inter arts etc.) poetesque tone is turns into a basic feature of the existing poetry that he opposes. From this point of view, the rejection of the poetesque tone is the rejection of the words that point to the sublime, the transcendence, the ideal that invite language as a burden to poetry and the forms in which these words take action. The poetic tone, which is at the opposite pole of the poetesque tone and gives Garip poetry its original identity, is not fully clarified
\end{abstract}

Dr. Öğr. Üyesi, Ondokuz Mayıs Üniversitesi, Fen Edebiyat Fakültesi, Yeni Türk Edebiyatı ABD (Samsun, Türkiye), bekirkonyali55@hotmail.com, ORCID ID: 0ooo-0oo1-9235-1294 [Araştırma makalesi, Makale kayit tarihi: 28.09.2021kabul tarihi: 20.10.2021; DOI: 10.29000/rumelide.1032434]

Adres | Address

RumeliDE Dil ve Edebiyat Araşturmalar Dergisi $\quad$ RumeliDE Journal of Language and Literature Studies Osmanağa Mahallesi, Mürver Çiçeği Sokak, No:14/8 $\quad$ Osmanağa Mahallesi, Mürver Çiçeği Sokak, No:14/8 Kadıköy - ÍSTANBUL / TÜRKIYE 34714 Kadıköy - ISTANBUL / TURKEY 34714 e-posta: editor@rumelide.com e-mail: editor@rumelide.com, tel: +90 505 7958124, +90 2167730616 phone: +90 505 7958124, +90 2167730616 
in the poetics of Garip poetry. One of the aims of this paper is to realize clarify this process by referring to the Garip poem itself and the criticisms and interpretations referance to it. Another aim is to make the background of the Garip poem visible by analyzing the poetic tone and to show the potentiality and problems of this understanding of poetry.

Keywords: Modern Turkish poetry, Orhan Veli, poetics, poetesque, poetic tone

\section{Giriş}

Meydana getirdiği köklü değişimden hareketle Modern Türk Şiiri içinde Birinci Yeni olarak da anılan Garip şiirinin temel yönelimi, o vakte kadar şiirin kuruluşunda gerekli ya da önemli görülen hususları şiir için bir yük telakki ederek şiirden çıkarmak olmuştur. Uygulamada kendini şiirlerde gösteren bu çıkarma işleminin teorik zemini poetikada (Garip Önsözünde) açıklığa kavuşturulur. Gerek teori (poetika) gerekse pratikleriyle (şiirler) şiirde hafiflik arayışı olarak adlandırılabilecek bu tutum, nesrin sınırına yaklaştırılan bir şiir tecrübesinde karar kılmış görünmektedir. Şiirin diğer sanatlarla ilişkisine son veren; şiirde vezne, kafiyeye, edebî sanatlara karşı çıan; şiirde konuşma diline yer açan bir anlayış ve uygulamada kendini gösteren bu hafif şür, Mehmet Kaplan'ın tespit ettiği şekliyle, fenomenolojik bir şiir arayışı olarak değerlendirilebilir. O şöyle demektedir:

"Fenomenolojik üslûp" diye adlandırabileceğimiz bu tasvir tarzında, varlık, araya hiçbir düşünce, hâtıra, çağrışım, benzetme vb. girmeden doğrudan doğruya veriliyor. Bu üslûp veya idrak tarzı, dil ve düşüncede büyük tasfiyeyi veya soyunmayı icap ettirir ki, Orhan Veli neslinin yaptığı da budur (1994, S. 135).

Buradan bakıldığında Garip şiiri “Donanımlarından arındııldığında hâlâ şiir olarak kalan nedir?”, "Şiir ile ilgili olduğu düşünülegelen hususlar bir fazlalık mıdır, gereklilik midir?” sorularını açığa çıaran bir araştırmadır. Ancak Orhan Veli'de bu araştırma, yer yer metodolojiyi de öngören bir hakikat arayışından ziyade, şiire bir hareket serbestisi kazandırma arayışı olarak dikkat çeker. Buna bağlı olarak, itiraz yüklü (tepkisel) bu yeni şiir tasarımının öncü şairi Orhan Veli’nin, şiiri serbest harekete (hafifliğe) müsait bir boş alanda inşa etmeye giriştiği söylenebilir. $\mathrm{Bu}$, aynı zamanda Garip önsözünün reddiyelerle ilerlemesini, diğer bir deyişle şiirin ne olmadığıyla bunca ilgilenmesini de daha anlaşılır kılmaktadır.

Orhan Veli’nin tesis etmeye çalıştığı, Garip önsözünde doğru dürüst konuşma diline yaslanan, saf, basit, alelade, tabii, iptidai kelimeleriyle anlaşılır kılınmaya çalışılan şiirin -onun yaklaşımıyla sahici şiïinşairanenin karşısında konumlandırdığı görülür. Aynı zamanda bütün hususiyeti edasında olan bu şiirin edası, şairane olmayan bir edadır. Ne var ki, eda ve şairanenin ne olduğu Garip önsözünde tam olarak açılığa kavuşturulmaz. Bu belirsizlik akla şu soruları getirmektedir: Kimi zaman şiirde itiraza konu bahislere eklenen kimi zamansa bu bahislerin sebebi olarak görülen şairane nedir? Eda nedir? Şairanenin reddi ve şiirin şairane olmayan edadan hareketle inşası neyi içermekte, neleri işaret etmektedir? Daha temelde Orhan Veli’nin şiir tasarımına yön veren nedir? Garip poetikasından, Garip şiirinden, bu poetika ve şiire getirilen itiraz ve eleştirilerden hareketle cevabı aranacak bu sorularla, hem işaret edilen kavramların anlaşılması hem de bu kavramlarla yönünü bulan Garip şiirinin temel duyarlık, imkân ve problemlerinin gösterilmesi amaçlanmaktadır.

\section{Bir karşı şiir olarak Garip}

Orhan Veli’nin Garip öncesi şiirleriyle dönemin mevcut şiir geleneği içinde başarılı sayılabilecek örnekler verdiği bilinmektedir. Onun, dönemin ferdiyetçi hece şairlerinin izlerini taşıyan Garip öncesi

\footnotetext{
Adres $\mid$ Address

RumeliDE Dil ve Edebiyat Araştırmaları Dergisi $\quad$ RumeliDE Journal of Language and Literature Studies Osmanağa Mahallesi, Mürver Çiçeği Sokak, No:14/8 Osmanağa Mahallesi, Mürver Çiçeği Sokak, No:14/8 Kadıköy - ÍSTANBUL / TÜRKIYE 34714 Kadıköy - ISTANBUL / TURKEY 34714 e-posta: editor@rumelide.com e-mail: editor@rumelide.com, tel: +90 505 7958124, +90 2167730616 phone: +90 505 7958124, +90 2167730616
} 
şiirlerini şekil, yapı, muhteva ve özellikle de şiir dili açısından başarılı bir başlangıç olarak gören Orhan Okay, şairin Garip şiirine geçişini psikolojik bir yaklaşımla izah eder:

Büyülü, rüyalı, hülyalı ve nostaljik duygular taşıyan "Oaristys", "Ebabil”, "Buğday", "Eva Maria”, "Odamda", "Masal" gibi şiirleriyle devam ettiği takdirde belki bir Türk şiirleri antolojisinde yer alacağını fakat döneminin aynı tarzda yazan büyük şairlerinin gölgesinde kalacağını fark etmiş olmalıdır. (2009, s. 67).

Okay'ın tespitlerinin dikkatimize sunduğu husus, Modern Türk Şiiri içinde öne çlkan pek çok şairde olduğu gibi Orhan Veli'nin de Garip’le birlikte bir zamanlar icracısı olduğu bir şiiri terk ve reddettiğidir. Bu terkin ve reddin yol açtığı Garip şiirinin mevcut şiir içinde sıkılan ve sıkışan iki şairin (Orhan Veli ve Oktay Rifat'ın) birbirinden habersiz kaleme aldıkları şiir denemelerini çekingen bir ifşayla paylaşmasıyla gün yüzüne çıktığını Oktay Rıfat'ın beyanından öğreniyoruz:

1937 yılının yaz aylarında, hangi ay olduğunu şimdi pek kestiremiyorum, güneşli bir gün. Orhan'la yan yana Özen'e doğru yürüdügüumüz gözümün önüne geliyor. Melih Belçika'da. (...) Şiir lafı ediyoruz. Piyasa şairlerinin şiirleri ikimizi de sarmıyor. Başka, bambaşka bir şiir hasreti ikimizin de içinde. Ben yeni bir şiir yazmışım, Orhan'a okumaya pek cesaret edemiyorum. Çünkü ne vezni var ne kafiyesi. Hem de birkaç satırlık bir şey. Adı: "Saksılar" (bu şiir ilk kitabımda vardır.) Bir ara boş verip okuyorum. Orhan kolay coşmaz. Coşuyor. Şu işe bakın ki o da cebinden dört satırlık bir şiir çıkarıyor. Adı: "Kelebek". Raymond Radiguet'ten tercüme etmiş. Bu sefer coşmak sırası bende. Sarmaş dolaş oluyoruz. O bambaşka şiire ilk adımı attığımızı biliyoruz (2011,s. 25).

Ardından Melih Cevdet'in de katıldığı bu yeni şiir, dergilerde yayınlanıp yaygınlaştıkça eleştiriler almaya başlar. Garip Poetikası hem bu eleştirilere ön almak hem de bu şiirin mevcut şiiri açma/ aşma yönündeki imkânlarını izah etmek üzere kaleme alınmış bir metin olarak görünmektedir. Birçok şairde görüldüğü gibi Orhan Veli'de de teoriye (poetika) yön ve imkân veren pratiğin (şiir) bizatihi kendisi olmuştur. Bu ise Orhan Veli'nin şiir anlayışını yüzeysel bir tepkisellik olarak anlamamıza imkân veren tespitlere ihtiyatla yaklaşmamızı gerektirmektedir.

Cemal Süreya'nın Orhan Veli'nin şiirde yok ettiklerinin (mısra, ölçü, müzik, imge, kafiye, metafizik, dram) sırf eski şiirde var diye yok edildiği tespiti bu minvalde hatırlanabilir (2017, s. 115). Benzer biçimde Okay da Garip şiirinin eski şiirle bir zıtlaşma hırsından doğduğu kanaatindedir (2009, s. 58). Orhan Veli’nin önce şiiri, sonra poetikayı yazmış olmasının bize düşündürdüğü, Orhan Veli şiirinin yok saydıklarını öncelikle şairin değil, şiirinin göstermiş olmasıdır. Başka bir deyişle bu şiirde veznin ve kafiyenin yokluğu; teşbih, istiare, mübalağa gibi söz sanatlarına başvurulmayışı; resim ve musikiden güç almama; Halman'ın Orhan Veli şiiri için kullandı̆̆ tabirle şehvetli ortalama insanın (I'hommemoyen sensuel) (2011, s. 368) dünyasına yaslanma (halkın zevki); konuşma diline yakınlı gibi özellikler şairin poetikasından bağımsız olarak okurun da tespit edebileceği hususlardır. Poetika olsa olsa bu özelliklerin nereden hareketle ve neden bu şiirde bulunduğunun bir izahıdır.

Bununla birlikte bu izahın tepkisellik olarak değerlendirilebilecek tarafları da mevcuttur. Söz konusu poetikada şiirin ne olduğu yerine ne olmadiğına ağırlı verilmesi ve reddedilen hususların dönem içindeki diğer şairlerin şiirlerini yoklayan tespitlerdeki polemik üslubu bu bağlamda düşünülebilir. Bu tavrın yeni bir şiire yer açmanın, bir iddia sahibi olmanın getirdiği aşırılıklar olduğunu Orhan Veli’nin şiir hakkında zaman içinde değişen düşüncelerinden anlıyoruz. Ancak bu değişimin, zamanında ve sonrasında tepki doğuran tespitlerinin reddini değil, yumuşatılmasını içerdiğini belirtmekte fayda var (Veli, 2014, s. 195-196). Yumuşama, Garip önsözünde şiirde reddedilen hususların şiirin yapımında hiç olmamasından, belirleyici olmamasına geçişi işaret eder. Baştan beri Orhan Veli, şiir ile birlikte düşünülen hususların (poetikada reddedilenler) alışkanlıktan kaynaklanan önyargılar olduğunu düşünmektedir. Ona göre şiir bu ile birliktelerle (vezin, kafiye, söz sanatları, sanatta tedahül vb.)

Adres Address

RumeliDE Dil ve Edebiyat Araştırmaları Dergisi $\quad$ RumeliDE Journal of Language and Literature Studies Osmanağa Mahallesi, Mürver Çiçeği Sokak, No:14/8 $\quad$ Osmanağa Mahallesi, Mürver Çiçeği Sokak, No:14/8 Kadıköy - ISTANBUL / TURKIYE 34714 Kadıköy - ISTANBUL / TURKEY 34714 e-posta: editor@rumelide.com $\quad$ e-mail: editor@rumelide.com, tel: +90 505 7958124, +90 216773 o 616 phone: +90 505 7958124, +90 2167730616 
güçlenmekte değil zayıflamaktadır. Varlığını ancak başkadan (ile birliktelerden) güç alarak duyurabilen şiirde şiir, ikincil kılınmaktadır.

Şiirin bağlantılı olduğu düşünülegelen hususlardan -Orhan Veli açısından önyargılardan- arındırılarak anlaşılma çabasının, deyiş yerindeyse şïri paranteze alma çabasının ortaya çıaracağı soru ise bellidir: Şiir alışkanlık ve önyargı olarak görülen vasıflardan (yük, donanım) arındığında, -bunun bir sonucu olarak manadan ibaret görüldüğünde- ona hâlâ şiir diyebilecek miyiz? Daha doğrudan bir deyişle bu şiirin nesirden ne farkı olacaktır?

\section{Şiirin parantezi: Şairane-eda}

Orhan Veli'nin Garip önsözünde bu soruya cevap olabilecek bir cümlesi bulunmaktadır: "Şiiri şiir yapan, sadece edasındaki hususiyettir; o da manaya aittir" (2014, s. 26). Metnin devamında şiirle nesir arasına çekilen bu ince çizginin (edanın) ne olduğu ile ilgili bir açlklamaya rastlamıyoruz. Okay'ın da belirttiği gibi bu, cümlenin nesir sentaksından ayrılmasından doğan bir şey olarak değerlendirilebilir (2009, s. 58). Bu noktadan bakıldığında söz gelimi:

Deli eder insanı bu dünya,

Bu gece, bu yıldızlar, bu koku,

Bu tepeden tırnağa çiçek açmış ağaç (Veli, 2014, s. 70)

dizelerini nesir sentaksına çevirmek, edanın ne olduğunun anlaşılmasını kolaylaştırabilir: "Bu dünya, bu gece, bu yıldızlar, bu koku, bu tepeden tırnağa çiçek açmış ağaç insanı deli eder." Okay’ın nesir sentaksına yakınlığıyla dikkat çektiği Robenson şiiri örneğinde dahi, şiiri nesirden farklı kılan edayı hissetmek mümkündür. Anlayabildiğimiz kadarıyla her iki örnekte de kelimeler şiir formundayken yargı cümlesi olmaktan kurtularak uçuculuğu, ucu açıklı̆̆ı, yayılmayı duyuran bir duruma dönüşmektedir.

Edanın Orhan Veli şiirine has bir özellik olmadığı, Garip önsözünde de fark edilir. Onun karşı çıktı̆̆ı şiirde de eda bulunmaktadır. O, bu şiirlerdeki edayı, şairanelik sıfatıyla adlandırmakta ve yermektedir. Orhan Veli'nin şiiri yalıtan ve arıtan paranteze alma işlemine yön veren şairanelik, önsözde şiirde karşı çlkılan unsurların bazen devamı, bazense nedeni ya da sonucu olarak okunabilecek bir yerde durmaktadır.

Ona göre şairanelik, mısracı zihniyetin bir ürünüdür. Bütün yerine parça güzelliğine odaklanan bu şiir anlayışı ("mısracı zihniyet"), uzun zaman içinde şiire yerleşen kelimelerin muhafazasını savunmaktadır. Dolayısıyla Süleyman Efendi ve nasır gibi kelimeleri şïre has kelime hazinesi içinde görmediğinden yadırgamaktadır. Oysa Orhan Veli’ye göre şiirin güzelliği bizatihi kelimelerde değil kelimelerle kurulan bütünlüktedir. Buradan bakıldığında şiiri zaman içinde yer edinmiş (gelenek) belirli kelimelere hasretmek, kelimelerin kendi edalarını kendilerinin tayin ettiği bir mecrada alışılagelen şiirin etrafında dönmekten başka bir sonuç doğurmayacaktır. O bunu şöyle belirtmektedir:

Bu edaya bizi kelimeler getirmiş. Fakat şiir zevkini, şiir telakkisini bugünkü cemiyetten alan insan çok kere aksi cihetten hareket etmekte, yani o kelimelerden evvel şairaneyi tanımaktadır. Bu edayı getirebilecek kelimelerden müteşekkil lügat; yazarken şairane olmak isteyen, okurken de şairaneyi arayan insanın kafasında zaruri olarak meydana gelir. O lügatin çerçevesinden kurtulmadıkça şairaneden kurtulmaya da imkân yok. Şiire yeni bir dil getirme cehdi işte böyle bir kurtulma arzusundan doğuyor (Veli, 2014, s. 30).

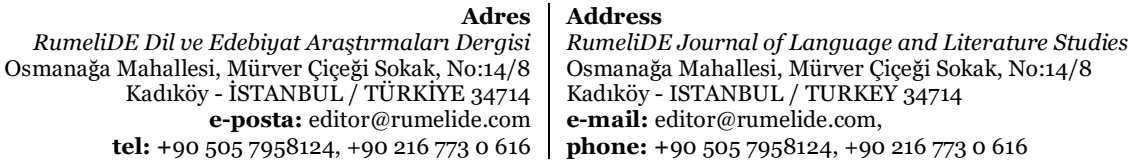

RumeliDE Dil ve Edebiyat Araştırmaları Dergis el: +90 505 7958124, +90 2167730616 
Bir açıdan bakıldığında şairanelik, şïre has kelime anlayışına itirazla şiirden tasfiye edilen diğer unsurların bir devamı niteliğindedir. Diğer açıdansa toparlayıcı bir merkezi önemi haizdir. Şöyle ki vezin, kafiye, söz sanatları, sanatta tedahül gibi hususlar şïre has kelimelerin şiirde örgütlenme formları olarak düşünüldüğünde şairanelik bir çatı kavrama dönüşecektir. Bu durumda tasfiye edilenin, birçok boyutuyla aslında şairanelik olduğu söylenebilir.

Toparlayıcı bir ifadeyle belirtilebilir ki, Orhan Veli açısından şiiri şiir yapan edadır ancak bu eda, şairane olmamalıdır. Orhan Veli'nin süregelende (gelenek) ikamet etmekte olan şairaneyi yerinden etmek üzere şiirlerinde iki yola başvurulduğu görülür: Birincisi mevcut kelimelerin şiire has kullanımının yapısını bozmak (tahattur, kitabe, kaside vb. sözcüklerin Orhan Veli şiirinde kazandığı anlamlar gibi), ikincisi ise pratik hayat ve konuşma dili içerisinde kenarda (marjda) kalan kelimeleri şiire taşımak (nasır, vesikalı yârim vb. sözcüklerde olduğu gibi). Böylece kelimeleri yerinden ederek şiir geleneğinin kabul ve alışkanlıklarını, bu kelimelere hayat ve hareket imkânı veren formların reddiyle ise şairaneyi şiirde görünür kılan araçları şiirden çıkarıyordu. Daha genel planda amaçlanan ise şairanenin eşlik ettiği alışılagelen şiir zevkini değiştirmekti. Güç kabul edilebilecek bir değişiklik olarak gördüğü zevkle birlikte o, şairaneye sebep olan zemine (zihniyete) yönelmektedir:

\begin{abstract}
Bugüne kadar burjuvazinin malı olmaktan, yüksek sanayi devriminin başlamasından evvel de dinin ve feodal zümrenin köleliğini yapmaktan başka hiçbir işe yaramamış olan şiirde, bu değişmeyen taraf; müreffeh sınıfların zevkine hitap etmiş olmak şeklinde tecelli ediyor. Müreffeh sınıfları yaşamak için çalışmaya ihtiyacı olmayan insanlar teşkil ederler. O insanlar geçmiş devirlerin hâkimidirler. O sınıfı temsil etmiş olan şiir layık olduğundan daha büyük bir mükemmeliyete erişmiştir. Ama yeni şiirin istinat edeceği zevk, artık ekalliyeti teşkil eden o sınıfın zevki değil. Bugünkü dünyayı dolduran insanlar yaşamak hakkını mütemadi bir didişmenin sonunda buluyorlar. Her şey gibi şiir de onların hakkıdır, onların zevkine hitap edecektir (Veli, 2014, s. 13).
\end{abstract}

Şairanelik bağlamında tespit ettiğimiz hususların şiirsel pratikler olarak döneminde Yahya Kemal ve Ahmet Haşim şiirine itirazları işaret ettiği söylenmiştir (Okay, 2009, s. 81). Ancak Orhan Veli şiirinin toplumcu şiirle (Nazım Hikmet) de mesafesi bilinmektedir ki önsözde Orhan Veli bunu "mesele bir sınıfın ihtiyaçlarının müdafaasını yapmak olmayıp sadece zevkini aramak, bulmak, sanata onu hâkim kılmaktır" (2014, s. 22) diyerek belirtir. Bu hatırda tutulduğunda şairaneliğin sadece şiir geleneği içinde yer tutan söylemlere ve dil kullanımlarına değil yücelik, aşkınlık, ideal ifade eden her dile mesafelenmeyi ima ettiği düşünülebilecektir.

Şiirde sadeliği, şiiri sadeleştirmeyi öne çıkaran bu araştırma (Garip şiiri), yükü (şairanelik) şiirin biçimsel kuruluşu ile sınırlı tutmamış, ona zemin teşkil eden tarihsel ve toplumsal ortamla da ilişkilendirerek şairaneliğin, bir şiir zevkinin sonucu olarak görülmesine imkân vermiştir.

Turgut Uyar'ın şairanelik hakkındaki tespitleri meselenin bir başka boyutuna ışık tutmaktadır. Orhan Veli'de belirli bir şïr zevkini ifade eden şairane, Turgut Uyar'da şürde takınılan tavır olarak yorumlanır. O şöyle demektedir:

Şiirde şairane’ye hep karşı oldum. Ama doğrusunu söylemek gerekirse, "bir dönemin şairanesi”ne. Değişen dünyayla bütünleşen şiir, hayattan yola çıkan, her dönemde kendi şairane'sini yaratır. Kaçınılmaz bir olgudur bu. Şairanelik, sadece sözcüklerde, imgelerde değildir, takınılan tavırdadır biraz da. Örneğin hece'nin şairanesi, gurbet'te, hasret'te, aşk kırgınları'nda idiyse, Garip'in şairane'si, kentli "küçük adam”ın, "bulduğu ile yetinirliği”nde, bir bakıma "vurdum duymazlı̆̆ı"ndadır (Uyar, 1981).

Uyar’ın ifadeleri göstermektedir ki, başlarda farklılığıyla dikkat çeken bir şiir sesi, güçlenince, başka bir deyişle ardıllarının oluşmasına imkân veren geniş bir etki dairesine ulaşınca, hatta ilerleyen zamanda

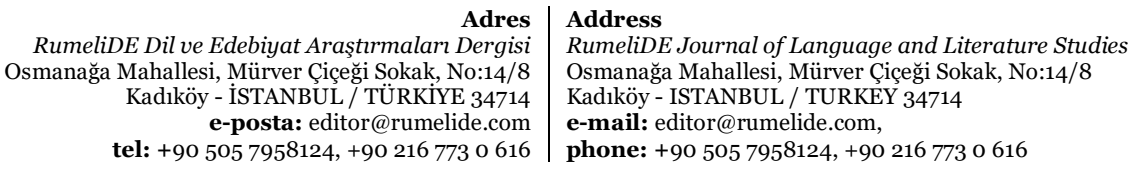


şiirin alımlanmasıyla ilgili, genel kanaat ve tavırların referansı olmaya başlayınca şairaneyi ortaya çıkarmaktadır. Dolayısıyla Uyar'ın tespitinden hareketle Garip şiiri için söz konusu edilebilecek şairane, bizatihi Garip şiirinde değil (Orhan Veli’nin kendi döneminde ve öncesindeki şiirle ilişkisinde olduğu gibi) bu şiirin zamanla kazandığı güçte, yani etki alanını genişleterek şiirin ne olduğu ile ilgili genel bir tavrı, bir bakıma şiir standardını belirliyor olmasındadır. Buradan bakıldığında her güçlü şiirin, onu sona yaklaştıran şairanesine yürüdüğü söylenebilir. Uyar’ın değerlendirmesi de bu noktaya ışık tutarak Garip şiirinin belirişine değil, çekilişine (şairanesi) dikkat çekmektedir.

Bu durumda kanıksanan şiire kişiyi yabancılaştıran, şiirle ilgili alışkanlıkları kırarak şiirin ne olduğuyla ilgili kişiyi yeniden düşünmeye davet eden ve öncelikle şiirin bizatihi kendisinde ortaya çıkan her uygulamanın şairaneye karşı bir kalkışma olduğu görülecektir. Buradan bakıldığında Orhan Veli’nin Garip Önsözünde yaptığı, devrinin şairanesinden uzaklaşan şiirinin açığa çıkardığı itiraz ve eleştirilerin nesir dilinde savunusu olmaktadır. Yukarıda belirtildiği gibi şairane olmayan eda kavramsallaştırmasıyla o, hem şiirin yapılış ve/veya kuruluşunda hâkim olan alışkanlıkları bertaraf etmeyi hem de zevk tabiriyle bu biçimin taşıdığı içeriği (zihniyeti) eleştirmeyi hedef almaktaydı. Ona göre şiir, taşıdığı yükü ve bu yüklerin neticesi olarak kazandığı formu tarihsel, toplumsal ve düşünsel ortamın süregelen uygulamalarından edinmiştir. Bu noktada denilebilir ki onun şiirle yaptığı, var olduğu dönemde ve öncesinde okura bağlarını hatırlatan ya da okurda bağ tesis etmeye çalışan ideoloji ve inanışların halka (okura) hakikati gösteren /duyuran şiirleri yerine halkın hakikatini şiire taşıyan bir noktada durmayı tercih etmek olmuştur. Ancak bu ne demektir? Hakikatin yön verdiği halk ile halkın yön verdiği hakikat birbirinde ayrı düşünülebilir şeyler midir, düşünülebilirse bunun sınırı nasıl çekilecektir?

\section{Şiirin baş aşağısı: eleştiri ve itirazlar}

Görebildiğimiz kadarıyla Garip şiirinin bu noktada yaptığı bir tersyüz etmedir. Önemliyi önemsiz, önemsizi önemli görmek ve göstermek suretiyle değer hiyerarşisini tersyüz ederek şiiri bir karnavala çevirmek ve insan gövdesinde kültür içinde bastırılan, saklanan bel altını bir yaşam enerjisi olarak öne çıkarmak. Gerek karnaval gerekse bel altı bu tersyüz etmenin öne çıardığı durumlardır. Karnaval havasını duyuran şaka, alay ve çocuksu söylemle bel altı yaşam enerjisi olarak adlandırdığımız içgüdülerin öne çıkarılmasını, bu neslin yaşadığı tarihsel, toplumsal, düşünsel ortamla ilişkilendiren Kaplan'ın tespitleri konuyu aydınlatıcı mahiyettedir:

Cahit Sıtkı ve Orhan Veli nesli ailelerinden ve okullarından kendilerini derinden ikna eden samimi ve hakiki hiçbir inanç edinememişlerdi. Onlarda, daha önceki nesillerin adeta boşluk duygusundan kurtulmak ister gibi sarıldıkları din, tarih ve geleneğe ait hiçbir şey yoktu. (...) Kendilerine düşünce diye telkin edilen düşünce ve sloganların iflas ettiğini gören bu nesil, içgüdülerine en sağlam gerçek diye sarıldı. (...) Cahit Sıtkı ve Orhan Veli nesli, artık ne dine, ne de tarihe inanıyorlardı. Onlar için sadece "yaşanılan an" mühimdi. Gençlik yıllarında André Gide’in "Dünya Nimetleri”ni okuyan bu nesil, "yaşama sevinci”ni adeta bir din haline getirdi. Fakat ölüm vardı sosyal sefalet ortadaydı. Bunlar yaşanılan anın tatlı aşına zehir katıyorlardı. Ölüme bir çare bulunamayacağına göre, yapılacak şey geçen günleri mümkün olduğu kadar hazla doldurmak ve sosyal sefaleti ortadan kaldırmaktı (1994, S. 111, 133).

Bu noktada denilebilir ki, ideoloji ve/veya inanışlar olarak kültürün insanı sorumluluğa koşan, ona sorumluluk sahibi bir varlık olduğunu hatırlatan söylemleriyle insana yükledikleri, Garip şïrinde görmezden gelinen ya da hedonist bir arka plan tarafından geçersizleştirilen şeylerdir. Tarihe ve topluma alacaklılık (hesap sorma) ya da borçluluk (hesap verme) üzerinden şekillenen kültürel söylem, Garip

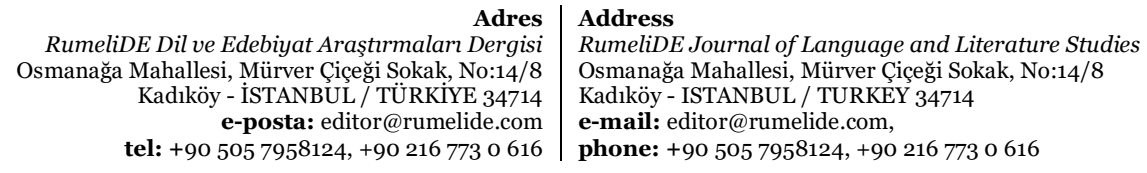


şiirinde paranteze alınmış bir yaşama sevinciyle dışarıda bırakılır ya da Hay-kay tarzı Böcekler ${ }^{2}$ şiirinde görüleceği gibi kültürden doğaya dönme arzusuyla yer değiştirir.

Garip şiirinin, başında kasketi, elinde elmasıyla (Süreya, 2017, s. 394) kitapları incelten, caddeleri genişleten (Ece Ayhan'dan aktaran Sazyek, 1999, s. 340) aylaklığı içinde yaşamı, ertelenmesi (gelecek) ya da hatırlanması (geçmiş) gereken değil, şu an hissedilip yaşanması gereken bir sevinç olarak görmesi; bir yönüyle içine doğduğu savaş, yoksulluk ve baskı ortamının gölgesindeki hayatı ve şiiri havalandırmadır. ${ }^{3}$ Aksi yönden ise aynı tutum halkın (sıradan insan) hakikatini geçim derdine, aşk, ölüm, savaş ve yoksulluktan duyulan acı ve çaresizliğe indirgeyen bir hümanizm olarak da değerlendirilebilir.

Bu noktada sıradan insanı (Süleyman Efendi), aleladeyi (nasır) verili bir şey içinlikten arındırarak şiire taşımak, şiire özgü ya da şiire yakışır kelimeleri arayan bir ciddiyet yerine yer yer çocuksu bir söylemle (sorumsuzluk), şakacı, alaycı bir mizahı karşıtlıklar içeren bir öykülemeyle4 sunmak, ortaya çıktığı dönem ve sonrasında garipsenmiş, kimi şairlerce Garipçiler, şiiri ayağa düşürmekle eleştirilmiş ve yerilmiştir.

İkinci Dünya Savaşı’nın yol açtığı değer buhranını ayağa düşürme olarak adlandırılan durumda etkili gören şairlerden Sezai Karakoç, Garip şiirini varoluşa açlık açısından bakan katı bir realizm ekolü olarak görür (2014, s. 46). Behçet Necatigil için de Garip şiiri, konuşma dilinin rahatlığıyla yazmanın sohbetten, yârenlikten farksızlaştığı, şairlerinin dünyaya ya çocuk duyarlığı, saflığı; ya da yetişkin fakat ancak kendi rahatına düşkün, sıradan, bön bir kimsenin basit tedirginlikleri içinde bakıp şaşırtmacalar yazdıkları bir şiirdir (2006, s. 165-167).

Etki dairesini övgü ve yergilerle genişleten Garip’in, bütün görünümleriyle şairanelikten arındırarak boşalttığı alanda tesis ettiği şiirin aranan özelliklerine bakıldığında tabiilik, aleladelik, doğru dürüst konuşma, saflk, basitlik, iptidailik, şuuraltı kelimelerinin öne çıtığı görülür. Önsözde bu kelimeler Garip şiirini tarif etmek üzere kullanılmaktadır. Bu kelimelerin ima ettiği ise verili dilin gerisine uzanma, deyiş yerindeyse şiir için arındırılmış bir sıfır noktası tayin etme olarak düşünülebilir.

Orhan Veli'ye göre vezin ve kafiye bir ihtiyaçtan (hafızaya yardımcı olma) doğmasıyla; teşbih, istiare, mübalağa gibi söz sanatları zekânın tabiata müdahalesi olmakla; sanatta tedahül, birbiri içine giren sanatların hakiki değerlerinden birçok şey yitirmesiyle tabiiliği, aleladeliği, saflı̆̆ı, basitliği zedelemektedir. Şiirde tasfiye edilen bütün bu unsurların mefhumu muhalifinden işaret ettiği; bunların şiirde suni, fevkaladelik uyandırmak üzere zorlayıcı, şiirin sadeliğini, açıklığını, anlaşırlığını bozucu alışkanlıklar olduğudur. Bu noktada şairane de şair gibi olmayı ifade etmekle bir sahici olmayışa işaret etmektedir. Daha genel planda bunun anlamı, şiirde medeniyetin ifade ettiği, medeniyet mahsulü kazanımlardan doğaya, insan doğasına, doğala dönüştür. Bu bağlamda Tanpınar’ın Orhan Veli şiiri üzerine tespitleri kanaatimizi doğrular niteliktedir:

Süleyman Efendi, 1910'dan sonra doğanların şiirinde görülen hususiyetlerin bir sınıfın adamında toplanmasıdır. Bu karakter, her türlü idealizmin ve değer hiyerarşisinin dışında ilk doğmuş insan

\footnotetext{
2 Düşünme Arzu et sade!

Bak, böcekler de öyle yapıyor (Veli, 2014, s. 53).

3 Havalandırma tabiri Oktay Rıfat'a aittir. Konuyla ilgili bir yazısında yol sormak için yanına yaklaşan bir köylüyle aralarında geçen konuşmayı aktardıktan sonra "Kıssadan hisse" diyerek ekler: " Garip hareketi her şeyden önce bir havalandırma hareketidir.” ( 2009, s. 227).

4 Sazyek, Garip şïrindeki başlıca anlatım tekniklerini karşıtlık, mizah ve öyküleme olarak tespit eder. (1999, s. 192-209)

Adres | Address

RumeliDE Dil ve Edebiyat Araştırmaları Dergisi $\quad$ RumeliDE Journal of Language and Literature Studies Osmanağa Mahallesi, Mürver Çiçeği Sokak, No:14/8 $\quad$ Osmanağa Mahallesi, Mürver Çiçeği Sokak, No:14/8 Kadıköy - ÍSTANBUL / TÜRKIYE 34714 Kadıköy - ISTANBUL / TURKEY 34714 e-posta: editor@rumelide.com e-mail: editor@rumelide.com, tel: +90 505 7958124, +90 2167730616 phone: +90 505 7958124, +90 2167730616
} 
yahut bilinmeyen ameliyelerden geçmiş ve transcendantal'le her türlü alakasını kesmiş bir mahlûk gibi sadece var olmakla yetinir (1992, s. 115-116).

Karakoç’un da katı realizm olarak adlandırdığı bu duruma bugünden hareketle getirilebilecek katkı, Orhan Veli'nin şairane olmayan eda (sahici şiir) arayışının modern bilincin tarihselliği içinde öne çlkan mevcudu tasfiye ederek yeniyi inşa diğer bir deyişle boş alanda sıfirdan inşa pratiklerinin etkisi altında şekillendiğini belirtmek olacaktır. Modernist bir metafiziği (katı realizm) işaret etmekle dikkat çeken katı bir realizm ekolü tespiti, aynı zamanda Orhan Veli şiirinin nesre yakınlı̆ının da bir izahı olmaktadır. Dilin ötesinde ya da gerisinde yer alarak ona yön veren biricik yetke olarak aklı merkeze alan kartezyen bir düşünüssle beliren bu yakınlıkta Orhan Veli’nin şiire tanıdı̆̆ı hareket serbestisi, bir gize ya da yüceye davet edegelen şiiri gezintiye çıkarmak olmuştur.

Bununla birlikte, geleneğin reddine dayanan bu tarz bir modern düşünüşün ancak gelenekle mümkün oluşunun doğurduğu paradoks aslında Orhan Veli’nin fark ettiği ve fakat görmezden geldiği bir güçlüktür:

Yapıyı temelinden değiştirmelidir. Biz senelerden beri zevkimize, irademize hükmetmiş, onları tayin etmiş, onlara şekil vermiş edebiyatların, o sıkıcı, o bunaltıcı tesirlerinden kurtulabilmek için o edebiyatların bize öğretmiş olduğu her şeyi atmak mecburiyetindeyiz. Mümkün olsa da "şiir yazarken bu kelimelerle düşünmek lazımdır" diye yaratıcı faaliyetimizi tahdit eden lisanı bile atsak. Ancak bu suretledir ki, kendimizi alışkanlıkların sürüklediği gayrı tabii inhiraftan kurtarmış; safiyetimize, hakikatimize irca etmiş oluruz (Veli, 2014b,s. 23).

Heidegger'in “Dil, varlığın evidir" (2013, s. 25) sözü ve bu sözde karşllı bulan günümüz dil felsefelerine yön veren yaklaşımların sonuçları doğru kabul edildiğinde denilebilir ki dil, gerisine uzanılabilecek bir gerçeklik değildir. Düşüncenin ve ifadenin daima dil içinde ve ancak dille gerçekleşebiliyor olması, geleneğin reddini ifade eden söylemlerin dil dışında aradıkları bir sahiciliği yanılsamaya dönüştürmektedir. Buradan bakıldığında kimi zaman redde kimi zamansa kabule konu olan gelenek (dil), yeniye her zaman bir yenilenme olarak anlam verecektir. Bu tespitlerden hareketle Orhan Veli'nin yukarıdaki ifadelerine bakıldığında görülecektir ki, atılamayan lisan, safiyetimizi de bir kurguya dönüştürmektedir.

$\mathrm{Bu}$ durumda modern bir dünyadaki sahicilik arayışı, takdir edildiğinde dahi daima melez bir karakter gösterecektir. Halman'ın Orhan Veli için belirttiği kentli halk ozan tabiri (2011, s. 368) ifadeye çalıştı̆̆ımız hususun anlaşılmasını kolaylaştırabilir. Bu tabirin bize gösterdiği halk ozanının ifade ettiği sahiciliğin (otantikliğin) Orhan Veli'de ancak kentlilikle geçerlilik kazanmasıdır. Kentli halk ozanı, bir flâneur (aylak adam)dür.

Kalabalık içerisinde yaşayan terk edilmiş bir kişi olarak flâneur, işi gücü olmayan birinin kişiliğine bürünerek gezinir; böylece insanları birer uzman yapan işbölümünü de protesto etmiş olur (Benjamin, 2011, s. 148,149). Benjamin'e göre özdeşleyim, flâneur'ün kalabalık içerisinde kendini kaptırdı̆̆ esrikliğin doğasını oluşturur (2011, s.149). Bu tespitinin açıklamasını Marx’tan alarak şöyle der:

Şair, gönlünce kendisi ve bir başkası olabilme gibi eşsiz bir ayrıcalıktan yararlanan insandır. Tıpkı bir beden aramak için dolanıp duran ruhlar gibi, şair de istediği zaman bir başkasının kişiliğine girer. Herkesin kişiliği ona açıktır; eğer belli yerler kapalıymış gibi gözüküyorsa, bunun nedeni o yerlerin şairin gözünde görülmeye değer olmayışıdır. (Marx’tan aktaran Benjamin, 2011, s. 149). 5

5 Serhat Demirel'in değerlendirmeleri Benjamin ve Marx’ın flâneur'e dair tespitlerinin Orhan Veli’deki karşllğ̆ gibidir: Gerçekte, Orhan Veli’nin şiiri bir tür örtmece üzerine kuruludur. Bunu, şairin kullandığı "poetik persona"lar üzerinden söyleyebiliyoruz. Şair, kurgusal bir şekilde, şiirsel özneyi alelade insanlardan biri olarak konuşturarak "ampirik okur"la yakınlık içine girer. Orhan Veli’nin başarısı da burada, Melih Cevdet’in tespitiyle, "ele aldığı kişinin deyişini temel Adres Address

RumeliDE Dil ve Edebiyat Araştrmaları Dergisi $\quad$ RumeliDE Journal of Language and Literature Studies Osmanağa Mahallesi, Mürver Çiçeği Sokak, No:14/8 $\quad$ Osmanağa Mahallesi, Mürver Çiçeği Sokak, No:14/8 Kadıköy - İSTANBUL / TÜRKIYE 34714 Kadıköy - ISTANBUL / TURKEY 34714 e-posta: editor@rumelide.com $\quad$ e-mail: editor@rumelide.com, tel: +90 505 7958124, +90 216773 o 616 phone: +90 505 7958124, +90 216773 o 616 
Kanaatimizce kentli halk ozanı olarak Orhan Veli'nin İstanbul (kent) gezen, İstanbul'da gezinen şiirinin gücü ve güçsüzlüğü, insanın ruh hallerini, bir aylak adam (flâneur) olarak bir arada tutmasından ileri gelmektedir. Orhan Veli'de şairane olmayan bir edaya yaslanan sahici şiirin nasıl bir zeminde yeşerdiğinin de izahını veren bu tespitten hareketle denilebilir ki, Orhan Veli'deki şiirsel öznenin adı konamayan bir eksikliğin ifadesi olan ve bedenin sınırlarını pek de aşmayan hüznünün ağırlı̆̆ı, platonik çağrışımlardan arınmış tensel bir aşkla, bazen ironik bir söyleme de kayan şakayla ve var olmakla yetinen kanaatkâr bir yaşama sevincini duyuran neşeyle dağllı toparlanmaktadır.

\section{Sonuç}

Süregelen şiir içindeki sıkılma ve sıkışmayı açmak ve aşmak üzere dile gelen, köklü bir değişimi fark ettirmesiyle garip bulunan Orhan Veli şiiri, dönemindeki mevcut şiire itirazlarını poetikadan (Garip Önsözü) önce şiiriyle yapmıştır.

Garip bulunan bu şiirin izah ve savunusu olan poetika, öncelikle zaman içinde kökleşen alışkınlıklar (mümarese) sonucu mevcut şiire imkân veren kanaatlerin bileşenlerini (vezin, kafiye vd.) şiir için bir fazlalık (yük) olarak tespit ve reddeder. Bir nevi yalıtma ve arındırma için şiiri paranteze alma olarak görülebilecek bu yaklaşım, ilişkili olduğu düşünülegelen bileşenleri şiirden atarak şiire hafiflik sağlar. Hafiflikle örtüşen konuşma dili, aleladelik, tabiilik, saflık, basitlik, iptidailik kelimelerinin yön verdiği bu sahici şiir arayışında şiir kendini edada temellendirir. Aynı zamanda şiirin nesirden farkına da işaret eden eda, anlayabildiğimiz kadarıyla nesrin yargıya varmak üzere vücut bulan sentaksından anlamın uçucu, ucu açık, yayılan bir durum olarak tecrübe edilmesine açılmakla ayrılmaktadır.

Karşı kutbunda yer alan şairane edayı Orhan Veli, mevcut şiirin kelime hazinesine kayıtlı ve mahkûm olmanın bir sonucu olarak görür. Ancak bu kelimelerin yukarıda anılan şiir bileşenleriyle hareket kazandığını düşündüğümüzde şairane eda bir bütün olarak karşı çıkılan mevcut şiirin temel bir vasfına dönüşmektedir. Buradan bakıldığında şairane edanın reddi, dili şiire bir ağırlık olarak davet eden; buna bağlı olarak da dilde yüceyi, aşkını, ideali işaret eden kelimelerin ve bu kelimelerin hareket kazandığı formların reddi olmaktadır.

Modern kent yaşamında hayatın nabzını sokakta tutan ve duyan İstanbul gezgini Orhan Veli şiiri; poetikasında bilincin dilin gerisine uzanabileceği bir noktayı varsaymış olmasıyla (sahici şiir) mistik ya da mitik olmayan başka bir metafiziğe (katı realizm) kapı aralamış görünmektedir.

\section{Kaynakça}

Benjamin, W. (2011). Pasajlar. (A. Cemal. Çev.). İstanbul: Yapı Kredi.

Demirel, S. (2019). Modern Türk şïrinde okur algıları (186o-1940) (Doktora tezi). Sakarya Üniversitesi, Sakarya.

Halman, T. S. (2011). Orhan Veli’nin edebiyatımıza katkıları ve şiirlerindeki "yenilik boyutları". S. Gümüş (Ed.), Orhan Veli Kanık içinde (s. 395-401). Ankara: Kültür ve Turizm Bakanlığı.

Heidegger, M. (2013). Hümanizm üzerine. (Y. Örnek. Çev.). Ankara: Türkiye Felsefe Kurumu.

alması”nda (2016: 24) yatmaktadır. Klasik şiiri çok iyi bilen, o yolda üstadlardan takdir kazanan șiirler de kaleme almıș olan Orhan Veli, şimdi bambaşka bir şey yapmak istiyor, şiirin içine kurguyu yedirerek başkalarının adına, başkasıymış gibi konuşmayı deniyordu. Melih Cevdet'in Orhan Veli’nin şiirinde geçen çok sevdiğim salatayı bile / aramaz mı olacaktım dizelerine atfen "Salatayı sevmez, hiç yemezdi" (2016: 25) şeklindeki tespiti Orhan Veli’nin şiirde "başkasıymış gibi" konuşabilmeyi başardığını yani "poetik persona”yı inandırıcı biçimde kullanabildiğini gözler önüne serer." (Demirel, 2019, S.525).

RumeliDE Dil ve Edebiyat Araştırmaları Dergisi Osmanağa Mahallesi, Mürver Çiçeği Sokak, No:14/8 Kadıköy - ÍSTANBUL / TÜRKIYE 34714 e-posta: editor@rumelide.com tel: +90 $5057958124,+902167730616$
Address

RumeliDE Journal of Language and Literature Studies Osmanağa Mahallesi, Mürver Çiçeği Sokak, No:14/8

Kadıköy - ISTANBUL / TURKEY 34714

e-mail: editor@rumelide.com,

phone: +90 $5057958124,+902167730616$ 
Horozcu, O. R. (2011). Orhan Veli’nin ardından. S. Gümüş (Ed.) Orhan Veli Kanık içinde (s. 25-31). Ankara: Kültür ve Turizm Bakanlığı.

Horozcu, O. R. (2009). Biraz Garip biraz Orhan Veli. F. Özdem (Ed.), Şïr konuşması içinde (s. 227-231). İstanbul: Yapı Kredi.

Kanık, O. V. (2014a). Genç şairden beklenen. A. Tunç \& İ. Yllmazyurt (Ed.), Şairin işi içinde (s. 195-197). İstanbul: Yapı Kredi.

Kanık, O. V. (2014b). Bütün şïrleri. İstanbul: Yapı Kredi.

Kaplan, M. (1994). Şiï tahlilleri 2. İstanbul: Dergâh.

Karakoç, S. (2014). Edebiyat yazıları II. İstanbul: Diriliş.

Necatigil, B. (2006). Düzyazılar I. İstanbul: Yapı Kredi.

Okay, M. O. (2009). Poetika dersleri. Ankara: Hece.

Sazyek, H. (1999). Cumhuriyet dönemi Türk şïrinde Garip hareketi. Ankara: Türkiye İş Bankası Kültür.

Süreya, C. (2017). Orhan Veli’nin yanlışı. S. Özpalabıyıklar (Ed.), Şapkam dolu çiçekle toplu yazılar I içinde (s. 114-118). İstanbul: Yapı Kredi.

Tanpınar, A. H. (1992). Edebiyat Üzerine Makaleler. İstanbul: Dergâh.

Uyar, T. (1981). “Turgut Uyar'la Söyleşi”. Gösteri Dergisi. http://tabutmag.com/turgut-uyar-siirdesairaneye-hep-karsi-oldum/(Erişim Tarihi: 20.06.2021)

RumeliDE Dil ve Edebiyat Araştırmaları Dergisi Osmanağa Mahallesi, Mürver Çiçeği Sokak, No:14/8 Kadıköy - İSTANBUL / TÜRKIYE 34714 e-posta: editor@rumelide.com tel: +90 $5057958124,+902167730616$
Address

RumeliDE Journal of Language and Literature Studies Osmanağa Mahallesi, Mürver Çiçeği Sokak, No:14/8

Kadıköy - ISTANBUL / TURKEY 34714

e-mail: editor@rumelide.com,

phone: +90 505 7958124, +90 2167730616 